\title{
Thyroid Hormone and Blood Metabolites Concentrations of Broiler Chickens Subjected to Feeding Time Restriction
}

\author{
A. Azis ${ }^{a}, *$ H. Abbas ${ }^{b}$, Y. Heryandi ${ }^{\text {b }}$ \& E. Kusnadi ${ }^{\text {b }}$ \\ ${ }^{a}$ Department of Animal Production, Jambi University \\ Kampus Pinang Masak, Mendalo Darat, Jambi Indonesia, 36361 \\ bepartment of Animal Production, Andalas University \\ Kampus Limau Manis, West Sumatera, Padang Indonesia \\ (Received 14-09-2011; accepted 15-03-2012)
}

\begin{abstract}
ABSTRAK
Penelitian ini bertujuan untuk menguji pengaruh pembatasan waktu makan terhadap konsentrasi hormon tiroid dan metabolit darah ayam broiler selama periode pembatasan dan pemulihan. Sebanyak 400 ekor ayam broiler unsexed strain Lohmann umur 7 hari ditempatkan pada 5 perlakuan dengan menggunakan rancangan acak lengkap dan dianalisa menggunakan ANOVA. Perlakuan terdiri atas: ransum yang diberikan ad libitum (R-0); ransum yang disediakan 2 jam pada pagi hari dari pukul 08:00-10:00 dan 2 jam pada sore hari dari pukul 16:00-18:00 dari umur 7 hingga 14 hari (R-1) dan umur 7 hingga 21 hari (R-2); ransum disediakan 4 jam pada pagi hari dari pukul 08:00-12:00 dan 4 jam pada sore hari dari pukul 16:00-20:00 dari umur 7 hingga 14 hari (R-3) dan umur 7 hingga 21 hari (R-4). Setiap perlakuan memiliki ulangan sebanyak 4 dengan jumlah ayam sebanyak 20 ekor/unit. Konsentrasi hormon tiroid dan plasma albumin pada R-2 dan R-4 lebih rendah $(P<0,05)$ daripada R-0 selama pembatasan waktu makan dari umur 7 hingga 21 hari. Konsentrasi hormon tiroid dan metabolit darah tidak berbeda nyata diantara semua perlakuan selama periode pemulihan dari umur 21 hingga 42 hari. Disimpulkan bahwa konsentrasi hormon tiroid triiodotironin dan tiroksin $\left(\mathrm{T}_{3}\right.$ dan $\mathrm{T}_{4}$ ) dan plasma metabolit darah (albumin) menurun selama pengaturan waktu makan 4 dan 8 jam/hari dari umur 7 hingga 21 hari, akan tetapi, kondisi demikian kembali normal selama periode pemulihan.
\end{abstract}

Kata kunci: broiler, hormon tiroid, metabolit darah, pengaturan waktu makan

\section{ABSTRACT}

The present study was conducted to determine the effect of feeding time restriction on thyroid hormone and blood metabolites concentration of broiler chickens during feed restriction and realimentation period. Four hundred of 7 days-old unsexed broiler chicken of Lohmann commercial strain were arranged in a completely randomized design with 5 treatments and analyzed based on ANOVA. The treatments were: chicks fed ad libitum as a control treatment (R-0); chicks had free access to feed during two periods of $2 \mathrm{~h}$ (08:00-10:00 and 16:00-18:00) from 7-14 d of age (R-1) and 7-21 $d$ of age (R-2); chicks had free access to feed during two periods of $4 \mathrm{~h}$ (08:00-12:00 and 16:00-20:00) from 7-14 d of age (R-3) and 7-21 d of age (R-4). The treatments consisted of 4 replicates with 20 chicks each. During feeding time restriction from 7 to $21 \mathrm{~d}$ of age, thyroid hormone and albumin plasma concentration of $\mathrm{R}-2$ and $\mathrm{R}-4$ were lower $(\mathrm{P}<0.05)$ than $\mathrm{R}-0$. There were no statistical differences among the treatments on thyroid hormone and blood metabolites during realimentation period from 21 to 42 $d$ of age. It is concluded that thyroid hormone triiodothrionine and thyroxine $\left(T_{3}\right.$ and $\left.T_{4}\right)$ and blood metabolite (albumin) decreased during feeding time restriction for 4 and $8 \mathrm{~h}$ per $\mathrm{d}$ from 7 to $21 \mathrm{~d}$ of age and it returns to normal during realimentation period.

Key words: broiler, thyroid hormone, blood metabolite, feeding time restriction

\footnotetext{
* Corresponding author:

E-mail: azis.abdul601@yahoo.co.id
} 


\section{INTRODUCTION}

Continuous genetic selection and improvement in nutrition have led to a very fast growth rate in modern broiler chicken strains. The early-life fast growth rate is accompanied by a number of problems, such as incidence of metabolic disorders and incidence of skeletal diseases (Olkowski et al., 2008). These situations most commonly occur with broilers that consume feed ad libitum. In addition, under feeding ad libitum, some chicks may develop a habit of feed over consumption (Svihus \& Hetland, 2001), and this condition does not always mean that broiler chicks are good status of health and welfare (Jang et al., 2009). Therefore, restriction on feed availability through feeding time restriction may be a solution to these problems. Overwhelming evidence exists that feeding time restriction improves feed efficiency compared with ad libitum feeding (62\% vs 58\%), increased production index (329.04 vs 304.27), and decreased feed cost $(6.42 \%)$ in production per $\mathrm{kg}$ body weight of broiler chickens (Svihus et al., 2010; Azis et al., 2011).

A number of variations of feed restriction including limiting the time of daily access to feed (Khetani et al., 2009; Onbasilar et al., 2009; Mohebodini et al., 2009), removal of feed for up to $8 \mathrm{~h}$ a d or skip-a-day feeding, allowing birds to feed only once/h and feeding once every other day (Demir et al., 2004; Khajali et al., 2007; El-Fiky et al., 2008; Benyi et al., 2009, 2010; Boostani et al., 2010; Saffar \& Khajali, 2010), have been evaluated but results have been conflicting (Navidshad et al., 2006; Cornejo et al., 2007; Khetani et al., 2009; Ghazanfari et al., 2010). However, Mohebodini et al. (2009) on the respective research indicated that although intermittent feeding through free access to feed during four periods of $2 \mathrm{~h}$ (06:00-08:00, 12:00-14:00, 18:00-20:00, and 24:0002:00) from 7-21 d of age had lower on body weight gain than control (436.3 vs $495.3 \mathrm{~g}$ ), but had no effect on weight gain during realimentation period from 22-42 d of age. Such inconsistencies may relate to different feeding strategies applied which may affect the chick performance.

Controversy of growth phenomenon during realimentation period showed inconsistency result. These differences showed that growth is still a complex phenomenon due to the physiological aspects involved such as the role of thyroid hormones triiodothyronine $\left(\mathrm{T}_{3}\right)$ and thyroxine $\left(\mathrm{T}_{4}\right)$ as the controlling metabolism and growth and condition of the blood metabolites as clinical indication is not widely disclosed. Blood profiling, initially used to detect subclinical disorders due to incorrect feeding, has recently been given more widely to evaluate the effects of different treatments on metabolic, nutritional and welfare conditions of animals (Bovera et al., 2007). Thyroid hormone concentration is closely related to protein synthesis and energy production (Smith et al., 2002), and that relate to the performance of growth and changes in energy metabolism of broilers (Zhan et al., 2007). The other research, Jang et al. (2009) reported that the quantitative and qualitative feed restrictions during $7 \mathrm{~d}$ from 8-14 d decreased plasma protein and albumin concentrations of broiler chickens. However, Boostani et al. (2010) reported that feed availability for 8 h/d from 7-21 d did not influence plasma proteins and albumin concentrations of broiler chickens.

Feeding time restriction is a feed restriction schedule which chicks have daily free access to feed for 4 and 8 hours per day in specific time. It is an alternative lower intensity of early feed restriction (Zhang et al., 2007) and it is less stressful (Susbilla et al., 2003). Such conditions may be possible due to broilers eat to their maximal physical capacity (Bokkers \& Koene, 2003) during the feed availability. Therefore, it is assumption that the feed restriction is not severe. There is a transient decrease in basal metabolic rate of feed restricted birds, leading to less energy required for maintenance (Rincon \& Leeson, 2002; Tolkamp et al,. 2005). It is, however, not clear whether feeding time restriction can reduce thyroid hormone and blood metabolites concentrations. The objective of the current study was to determine the effect of feeding time restriction on thyroid hormone and blood metabolites concentration of broiler chickens during feed restriction and realimentation period.

\section{MATERIALS AND METHODS}

\section{Birds, Feed, and Cage}

A total of 400 unsexed Lohmann broiler chicks bought from commercial hatchery (PT Multi Breeder Adirama Indonesia Tbk, Lampung Indonesia), were used in current study. Chicks were fed commercial starter diet (crumble) from 7-21 d of age, and commercial finisher diet (pellet) from 22-42 d of age. The commercial feed purchased from Poultry Shop (manufacture by PT JAPFA Comfeed, Lampung Indonesia). The nutrient composition of commercial feed is presented in Table 1. All the chicks were reared in a conventional open-sided house with natural cyclic temperatures (minimum, 20 ${ }^{\circ} \mathrm{C}$; maximum, $34{ }^{\circ} \mathrm{C}$ ). The chicks were assigned to 20 floor pens with 20 chicks/pen $(1 \times \mathrm{w} \times \mathrm{h} ; 2 \times 1.5 \times 0.75$ $\mathrm{m})$.

Table 1. Nutrient composition of commercial starter (7-21 d) and finisher diet $(22-42 \mathrm{~d})^{*}$

\begin{tabular}{lrr}
\hline \multirow{2}{*}{ Nutrient composition } & \multicolumn{2}{c}{ Feed } \\
\cline { 2 - 3 } & Starter & Finisher \\
\hline Dry matter (\%) & 87.18 & 88.64 \\
Crude protein (\%) & 22.18 & 20.24 \\
Ether extract (\%) & 6.12 & 7.06 \\
Crude fiber (\%) & 3.31 & 3.83 \\
Nitrogen free extract (\%) & 5.08 & 51.97 \\
Ash (\%) & 5.49 & 5.54 \\
Ca (\%) & 1.52 & 1.49 \\
P (\%) & 0.77 & 0.65 \\
NaCl (\%) & 0.36 & 0.28 \\
GE (kkal/kg) & 3924.00 & 3875.00 \\
\hline
\end{tabular}

Note: ${ }^{*}$ ) Laboratory Feed Science and Technology, Bogor Agricultural University (2010) 


\section{Blood Sampling and Measurement of Parameter}

On d 14 and 21 (end feed restriction) and 42 (end realimentation period), blood samples were collected from a brachial vein of 2 chicks randomly selected birds from each pen using disposable syringe $( \pm 3 \mathrm{ml} /$ chick). The blood samples were collected directly into testtube with anticuagulant ethylenediaminetetraaceticacid; EDTA $(1.5 \mathrm{mg} / \mathrm{ml})$. Thereafter, the blood samples were centrifuged at $3000 \mathrm{rpm}$ for $5 \mathrm{~min}$ and plasma was harvested and kept frozen at $-30{ }^{\circ} \mathrm{C}$ until analyzed. Hormone analyses $\left(\mathrm{T}_{3}\right.$ and $\left.\mathrm{T}_{4}\right)$ on the plasma samples were performed by radioimmunoassay (RIA) using standard commercial kits according to the procedure of Izotop, Institute of Isotopes Co Ltd, (2010). The range of standard to made curve standard of $\mathrm{T}_{3}$ concentration from 0.1-100 nmol/dl. $\mathrm{T}_{3}$ concentration was analyzed directly in the plasma with a volume $100 \mu$ l. The range of standard to made curve standard of $\mathrm{T}_{4}$ concentration was from 10-1000 nmol/dl. $\mathrm{T}_{4}$ concentration was analyzed directly in the plasma with a volume $25 \mu \mathrm{l}$. Each sample was in duplicate determination and radioactivity $\mathrm{T}_{3}$ and $\mathrm{T}_{4}$ were counted by gamma counter. Blood metabolite concentrations (plasma protein and albumin) were determined by enzymatic techniques using a commercial kit (ReiGed Diagnostics, Italy) according to the procedure of Gowenlock et al. (1988). The range of standard to made curve standard of plasma protein (0.1$10 \mathrm{~g} / \mathrm{dl})$ and albumin concentrations (0.11-6 g/dl) with a volume $10 \mu \mathrm{l}$. Each sample was in duplicate determination and plasma protein and albumin concentrations measured by spectrophotometer (Spectronic Hitachi U2001) with wavelength at 520 and $580 \mathrm{~nm}$, respectively. All concentrations of plasma protein and albumin were in the range of standard. Globulin concentration was determined from the difference between the value of protein and albumin.

\section{Treatments and Experimental Design}

Broiler chickens had free access to feed from 1-6 d of age. On $7 \mathrm{~d}$, all birds were weighed and randomly allocated to each of five experimental treatments. The treatments were: chicks fed ad libitum as a control treat- ment (R-0); chicks had free access to feed during two periods of $2 \mathrm{~h}$ (08:00-10:00 and 16:00-18:00) from 7-14 d of age (R-1) and 7-21 d of age (R-2); chicks had free access to feed during two periods of $4 \mathrm{~h}$ (08:00-12:00 and 16:00-20:00) from 7-14 d of age (R-3) and 7-21 d of age $(\mathrm{R}-4)$. The treatments were arranged in a completely randomized design with 4 replications. All data were analyzed based on ANOVA and the significant differences between treatment means were determined by LSD based on testing at $\mathrm{P}<0.05$ (Steel \& Torrie, 1991).

\section{RESULTS AND DISCUSSION}

\section{Hormone Thyroid $\left(T_{3}\right.$ and $\left.T_{4}\right)$ Concentrations}

Stress induced by feed restrictions may reflect in dramatic change plasma biochemical. Previous studies in chickens showed that the feed restriction may modified the concentration of hormones that modulate energy metabolism and growth, such as hormone $\mathrm{T}_{3}$ and $\mathrm{T}_{4}$ (Decuypere et al., 2005; Zhan et al., 2007). Measurement of $\mathrm{T}_{3}$ and $\mathrm{T}_{4}$ hormone concentrations in blood plasma of broiler chickens carried out at the end of restriction period (14 and $21 \mathrm{~d}$ of age) and the end realimentation period (42 d of age). The concentrations of hormones $T_{3}$ and $\mathrm{T}_{4}$ were presented in Table 2 .

Hormone $\mathrm{T}_{3}$ and $\mathrm{T}_{4}$ concentrations of feed restricted broilers (R-1, R-2, R-3 and R-4) did not differ with the broilers fed ad libitum (R-0) at 14 days of age. However, concentrations of $\mathrm{T}_{3}$ and $\mathrm{T}_{4}$ in the restricted broilers of $\mathrm{R}$ 4 and R-2 had significantly lower $(\mathrm{P}<0.05)$ than those ad libitum broilers (R-0) at $21 \mathrm{~d}$ of age. During this period, $\mathrm{T}_{3}$ in $\mathrm{R}-2$ was lower $(\mathrm{P}<0.05)$ than $\mathrm{R}-4$, and there was no statistical differences between the R-2 and $R 4$ on $T_{4}$ concentration. These findings showed that the feeding time restriction for $7 \mathrm{~d}$ did not decrease circulating of $\mathrm{T}_{3}$ and $\mathrm{T}_{4}$. These findings accordance with findings Khajali et al. (2007) also reported that there were no difference between feed restricted broilers through skip-a-day feeding at age 9,11 , and $13 \mathrm{~d}$ with control on $\mathrm{T}_{3}(3.21$ vs $3.47 \mathrm{ng} / \mathrm{ml})$ and $\mathrm{T}_{4}(62.11 \mathrm{vs} 68.06 \mathrm{ng} / \mathrm{ml})$ at $28 \mathrm{~d}$ of age. However, the thyroid hormone $\left(\mathrm{T}_{3}\right.$ and $\left.\mathrm{T}_{4}\right)$ concentrations decreased when feed restriction was applied for $14 \mathrm{~d}$ from 7-21 d of age. This fact is in agreement with

Table 2. The concentrations of triidothyronine $\left(\mathrm{T}_{3}\right)$ and thyroxine $\left(\mathrm{T}_{4}\right)$ in the plasma of broilers

\begin{tabular}{ccccccc}
\hline & & \multicolumn{5}{c}{ Treatments } \\
\cline { 3 - 7 } Hormone & Age $(\mathrm{d})$ & $\mathrm{R}-0$ & $\mathrm{R}-1$ & $\mathrm{R}-2$ & $\mathrm{R}-3$ & $\mathrm{R}-4$ \\
\hline & & $1.87 \pm 0.38$ & $1.46 \pm 0.80$ & $1.48 \pm 0.49$ & $1.45 \pm 0.14$ & $1.45 \pm 0.05$ \\
$\mathrm{~T}_{3}(\mathrm{nmol} / \mathrm{l})$ & 14 & $1.29 \pm 0.14^{\mathrm{a}}$ & $1.23 \pm 0.05^{\mathrm{a}}$ & $0.72 \pm 0.12^{\mathrm{c}}$ & $1.22 \pm 0.11^{\mathrm{a}}$ & $0.96 \pm 0.11^{\mathrm{b}}$ \\
& 21 & $0.60 \pm 0.17$ & $0.63 \pm 0.17$ & $0.89 \pm 0.27$ & $0.92 \pm 0.27$ & $1.01 \pm 0.75$ \\
& 42 & $3.89 \pm 0.77$ & $4.70 \pm 0.53$ & $5.05 \pm 0.31$ & $5.04 \pm 1.50$ & $5.10 \pm 0.42$ \\
$\mathrm{~T}_{4}(\mathrm{vg} / \mathrm{dl})$ & 14 & $5.59 \pm 0.66^{\mathrm{a}}$ & $5.21 \pm 0.28^{\mathrm{a}}$ & $4.07 \pm 0.52^{\mathrm{b}}$ & $5.31 \pm 0.40^{\mathrm{a}}$ & $4.16 \pm 0.24^{\mathrm{b}}$ \\
& 21 & $6.19 \pm 0.37$ & $5.67 \pm 1.14$ & $5.43 \pm 0.81$ & $5.70 \pm 1.28$ & $5.65 \pm 0.61$ \\
\hline
\end{tabular}

Note: Means in the same row with different superscript differ significantly $(\mathrm{P}<0.05)$. Chicks fed ad libitum (R-0); chicks had free access to feed during two periods of $2 \mathrm{~h}$ (08:00-10:00 and 16:00-18:00) from 7-14 d of age (R-1) and 7-21 d of age (R-2); chicks had free access to feed during two periods of $4 \mathrm{~h}$ (08:00-12:00 and 16:00-20:00) from 7-14 $\mathrm{d}$ of age (R-3) and 7-21 d of age (R-4). 
the findings of Zhan et al. (2007) that the concentration of hormones $\mathrm{T}_{3}\left(1.7\right.$ vs $2.1 \mathrm{ng} / \mathrm{ml}$ ) and $\mathrm{T}_{4}$ (55.3 vs 60.5 $\mathrm{ng} / \mathrm{ml}$ ) in feed withdrawal for $4 \mathrm{~h} / \mathrm{d}$ (14:00 to 18:00) from 1-21 d of age were lower than the control.

Evaluation of plasma biochemistry in bird allows the identification of metabolic alterations due to a realm of factors, including genetic type, husbandry conditions, age, physiological state and pathological (Harr, 2002; Gayathri et al., 2004; Jurani et al., 2004; Alonso-Alvarez, 2005). Changes of blood thyroid hormone concentrations are an indirect measure of the changes in thyroid gland activity and circulating thyroid hormones can be considered as indicators of the metabolic and nutritional status of the animals (Todini, 2007; Todini et al., 2007).

The changes in plasma thyroid hormones concentration in feed restricted broilers likely result from a shift in the balance between deiodination of $\mathrm{T}_{4}$ by hepatic D1 and $\mathrm{T}_{3}$ degradation by hepatic D3 deiodinases (Darras et al., 2000; Ryens et al., 2002). The other report, Gyorffy et al. (2009) found that during energy restriction, $T_{3}$ concentration is lowered due to a decreased $\mathrm{T}_{4}$ activation and increased $\mathrm{T}_{3}$ inactivation. Furthermore, they show that hepatic type-I deiodinase (D1) is not affected by energy restriction, however, hepatic D2 is decreased on both transcriptional and enzyme activity levels. The thyroid hormones, including $\mathrm{T}_{3}$ and $\mathrm{T}_{4^{\prime}}$ are recognized as the key metabolic hormones of the body, with $\mathrm{T}_{3}$ being the most functionally active form. The majority of circulating $\mathrm{T}_{3}$ is derived from the deiodination of $\mathrm{T}_{4}$ in nonthyroidal tissues such as the liver and kidney (Smith et al., 2000). Decrease in activity monodeiodinase during feed restriction is part the changes of $\mathrm{T}_{3}$ concentration. Therefore, it was supposedly that metabolic rate decreased during feed restriction causes hormonal activity associated with energy metabolism and growth declined. This result is in line with observation of Azis et al. (2011) who found that growth performance of broilers decrease during feed restriction. This might be caused by the low basal metabolism and thus allows the organism to spare energy by decreasing basal metabolism (Hornick et al., 2000). Zhang et al. (2007) summarized that concentration of thyroid hormones were closely correlated with growth performance and shift the energy metabolism of broilers.

At the end period of realimentation (42 $\mathrm{d}$ of age), $\mathrm{T}_{3}$ and $\mathrm{T}_{4}$ concentrations in all feed restricted broilers were no differences $(\mathrm{P}>0.05)$ than those ad libitum broilers. Gonzales et al. (1998) reported that quantitative restriction (20\% ad libitum) from 8-21 d were not differences with control in $\mathrm{T}_{3}(1.30 \mathrm{vs} 1.32 \mathrm{ng} / \mathrm{ml})$ and $\mathrm{T}_{4}(9.46 \mathrm{vs} 8.91$ $\mathrm{ng} / \mathrm{ml}$ ) at $42 \mathrm{~d}$ of age. In addition, Zhan et al. (2007) reported that the concentration of $\mathrm{T}_{3}(1.1 \mathrm{vs} 1.0 \mathrm{ng} / \mathrm{ml})$ and $\mathrm{T}_{4}(63.3 \mathrm{vs} 65.7 \mathrm{ng} / \mathrm{ml})$ in feed withdrawal for $4 \mathrm{~h} / \mathrm{d}(14: 00$ to $18: 00)$ from $1-21 \mathrm{~d}$ of age were not differences than the control during the period of realimentation from 21-62 d of age. It suggests that degree of feed restrictions applied was not severe because there was a very fast adaptive response with small and transient alterations in $\mathrm{T}_{3}$ and $\mathrm{T}_{4}$ concentrations during the period of realimentation. This might be caused by increased activity of the enzyme deiodinase type III (D3) during the realimentation period would recover concentrations of $\mathrm{T}_{3}$ hormone (Darras et al., 2000; Gyorffy et al., 2009). Furthermore, Gyorffy et al. (2009) explained that hypothalamic feedback was not involved in the changes in serum $\mathrm{T}_{3}$ and $\mathrm{T}_{4}$ concentrations. These findings indicate that $\mathrm{T}_{4}$ and $\mathrm{T}_{3}$ concentrations of the feed restricted broiler were normalized and remain as the value of ad libitum broilers during realimentation period. These results accordance with findings Azis et al. (2011) that feed restricted broilers during starter period (7-21 d of age) had normal growth during realimentation period (21-42 d of age) so that compensatory growth and normal body weight could be achieved at $42 \mathrm{~d}$ of age.

\section{Blood Metabolites Concentration}

Plasma albumin concentration of feed restricted broilers ( $\mathrm{R}-2$ and $\mathrm{R}-4)$ were lower $(\mathrm{P}<0.05)$ than $\mathrm{R}-0, \mathrm{R}-1$, and $\mathrm{R}-3$ at $21 \mathrm{~d}$ of age, and there was difference between R-2 and R-4 on the concentration of albumin during this period (Table 3). These findings indicate that plasma albumin concentration decreased due to feeding time restriction for 4 or $8 \mathrm{~h} / \mathrm{d}$ during 7-21 d of age. Decrease of plasma albumin concentration during feed restriction associated with thyroid hormone status. About $50 \%$ of $\mathrm{T}_{3}$ is associated with albumin, and $75 \%$ of $\mathrm{T}_{4}$ is attached to albumin (Butler, 1983). These results in line with ElFiky et al. (2008) that feed availability for $4 \mathrm{~h} / \mathrm{d}$ with two periods of $2 \mathrm{~h}$ (7:00 to 9:00 and 12:00 to 14:00) decreased plasma albumin concentration of broiler (2.10 vs 2.63 $\mathrm{g} / \mathrm{dl}$ ) at $35 \mathrm{~d}$ of age. The other report, Jang et al. (2009) found that plasma albumin concentrations of broiler subjected to feed restrictions (70\% ad libitum) from 8-14 $\mathrm{d}$ of age is lower than the control at $14 \mathrm{~d}$ of age (0.82 vs $1.26 \mathrm{~g} / \mathrm{dl})$. Nevertheless, these findings differ with Demir et al. (2004) that feed withdrawal for $16 \mathrm{~h} / \mathrm{d}$ from $13-21 \mathrm{~d}$ of age was not influence plasma albumin of broilers at the end feed restriction (123 vs $117 \mathrm{~g} / \mathrm{dl}$ ). These differences in findings may be due to the differences in the intensity of feed restriction, time of feed restriction, age of initiation feed restriction, and the availability of feed for birds.

At the end period of realimentation ( $42 \mathrm{~d}$ of age), the concentrations of plasma albumin in all feed restricted broilers were no differences $(\mathrm{P}>0.05)$ than those ad libitum broilers. These findings indicate that plasma albumin concentrations of the feed restricted broiler were normalized and remain as the value of ad libitum broilers during realimentation period. Result of the present study was in agreement with the results of El-Fiky et al. (2008) and Boostani et al. (2010) who also show that plasma albumin concentrations were not affected by feed availability for $4 \mathrm{~h} / \mathrm{d}(2.03 \mathrm{vs} 2.14 \mathrm{~g} / \mathrm{dl})$ at $49 \mathrm{~d}$ of age, and feed availability for $8 \mathrm{~h} / \mathrm{d}(1.74 \mathrm{vs} 1.78 \mathrm{~g} / \mathrm{dl})$ at $42 \mathrm{~d}$ of age.

The concentration of total protein, globulin and albumin/globulin ratio $(\mathrm{A} / \mathrm{G})$ in all feed restricted broilers were no differences $(P>0.05)$ than those ad libitum broilers at the end of feed restriction and realimentation period. These results indicate that the plasma total protein and globulin have not changed due to feed restriction. Although there were indications of intake protein decreased (12.77 vs $15.04 \mathrm{~g} / \mathrm{bird} / \mathrm{d})$ during feed restriction from 7-21 d of age (Azis et al., 
Table 3. The concentrations of total protein, albumin, globulin and albumin/globulin ratio $(\mathrm{A} / \mathrm{G})$ in the plasma of broilers

\begin{tabular}{lcccccc}
\hline \multirow{2}{*}{ Blood metabolites } & Age $(\mathrm{d})$ & \multicolumn{5}{c}{ Treatments } \\
\cline { 3 - 7 } & & $\mathrm{R}-0$ & $\mathrm{R}-1$ & $\mathrm{R}-2$ & $\mathrm{R}-3$ & $\mathrm{R}-4$ \\
\hline Total protein $(\mathrm{g} / \mathrm{dl})$ & 14 & $3.12 \pm 0.56$ & $3.21 \pm 0.16$ & $2.97 \pm 1.06$ & $2.76 \pm 0.43$ & $2.56 \pm 0.90$ \\
& 21 & $4.61 \pm 0.49$ & $4.35 \pm 0.91$ & $4.77 \pm 0.26$ & $3.92 \pm 0.32$ & $3.86 \pm 0.58$ \\
& 42 & $5.19 \pm 0.38$ & $5.07 \pm 0.27$ & $5.01 \pm 0.22$ & $5.03 \pm 0.33$ & $5.02 \pm 0.18$ \\
Albumin (g/dl) & 14 & $1.70 \pm 0.17$ & $1.62 \pm 0.07$ & $1.64 \pm 0.06$ & $1.63 \pm 0.09$ & $1.63 \pm 0.04$ \\
& 21 & $1.62 \pm 0.11^{\mathrm{a}}$ & $1.70 \pm 0.09^{\mathrm{a}}$ & $1.48 \pm 0.03^{\mathrm{b}}$ & $1.63 \pm 0.09^{\mathrm{a}}$ & $1.41 \pm 0.03^{\mathrm{b}}$ \\
Globulin (g/dl) & 42 & $1.73 \pm 0.04$ & $1.82 \pm 0.08$ & $1.86 \pm 0.10$ & $1.77 \pm 0.14$ & $1.70 \pm 0.05$ \\
& 14 & $1.42 \pm 0.50$ & $1.59 \pm 0.20$ & $1.33 \pm 1.06$ & $1.13 \pm 0.44$ & $0.93 \pm 0.89$ \\
A/G Ratio & 21 & $2.99 \pm 0.53$ & $2.65 \pm 0.95$ & $2.45 \pm 0.32$ & $3.14 \pm 0.23$ & $2.45 \pm 0.58$ \\
& 42 & $3.46 \pm 0.39$ & $3.26 \pm 0.29$ & $3.15 \pm 0.12$ & $3.26 \pm 0.47$ & $3.32 \pm 0.22$ \\
& 14 & $1.32 \pm 0.46$ & $1.04 \pm 0.17$ & $2.09 \pm 1.51$ & $1.74 \pm 1.01$ & $1.79 \pm 0.32$ \\
& 21 & $0.55 \pm 0.11$ & $0.70 \pm 0.23$ & $0.52 \pm 0.04$ & $0.61 \pm 0.10$ & $0.60 \pm 0.15$ \\
& 42 & $0.51 \pm 0.06$ & $0.56 \pm 0.07$ & $0.60 \pm 0.02$ & $0.56 \pm 0.12$ & $0.52 \pm 0.05$ \\
\hline
\end{tabular}

Note: Means in the same row with different superscript differ significantly $(\mathrm{P}<0.05)$. Chicks fed ad libitum (R-0); chicks had free access to feed during two periods of $2 \mathrm{~h}$ (08:00-10:00 and 16:00-18:00) from 7-14 d of age (R-1) and 7-21 d of age (R-2); chicks had free access to feed during two periods of $4 \mathrm{~h}$ (08:00-12:00 and 16:00-20:00) from 7-14 $\mathrm{d}$ of age (R-3) and 7-21 d of age (R-4).

2011), however, it would not decrease protein reserves in the body. Plasma protein was an indication of protein reserve in the body that can reflect the ability of the chicken store "reserve" protein even after the animal has reached its maximum capacity for depositing tissue. The importance of such reserve in resisting the stresses of caloric restriction (Leveille \& Sauberlich, 1961). Contrary to this finding, Jang et al. (2009) found that total protein concentrations of broiler subjected to feed restrictions (70\% ad libitum) from 8-14 d of age was lower than the control at $14 \mathrm{~d}$ of age (1.96 vs $3.26 \mathrm{~g} / \mathrm{dl})$, however, it had similar level (2.76 vs $2.12 \mathrm{~g} / \mathrm{dl})$ at the end realimentation period ( $35 \mathrm{~d}$ of age). This finding indicate that feeding time restriction had lower intensity of feed restriction, so that there was not any change reserve protein during feed restriction. The other repots, the feed restriction through feed availability for $8 \mathrm{~h} / \mathrm{d}$ during 7-21 d of age (Boostani et al., 2010), and skip-a-day for $6 \mathrm{~d}$ during 8-18 d (Bratte, 2011) were not influence plasma protein concentrations at age of $42 \mathrm{~d}(3.76 \mathrm{vs} 3.89 \mathrm{~g} / \mathrm{dl})$ and $56 \mathrm{~d}$ (5.60 vs $6.40 \mathrm{~g} / \mathrm{dl})$.

\section{CONCLUSION}

Thyroid hormone $\left(\mathrm{T}_{3}\right.$ and $\left.\mathrm{T}_{4}\right)$ and blood metabolite (albumin) concentrations decreased during feeding time restriction for 4 and $8 \mathrm{~h}$ per $\mathrm{d}$ from 7-21 d of age, but any influence was not observed on thyroid hormone and blood metabolites concentrations during realimentation period.

\section{REFERENCES}

Alonso-Alvarez, C. 2005. Age-dependent changes in plasma biochemistry of yellow legged gulls (Larus cachinnans). Comp. Biochem. Phys. A 140: 512-518.

Azis, A., H. Abbas, Y. Heryandi, \& E. Kusnadi. 2011. Pertum- buhan kompensasi dan efisiensi produksi ayam broiler yang mendapat pembatasan waktu makan. Med. Pet. 34: 50-57. DOI: 10.5398/medpet.2011.34.1.50.

Benyi, K., O. Acheampong-Boateng, D. Norris, M. Mathoho, \& M. S. Mikasi. 2009. The response of Ross 308 and Hybro broiler chickens to early and late skip-a-day feed restriction. Trop. Anim. Health Prod. 41: 1707-1713. DOI:10.1007/ s11250-009-9369-9.

Benyi, K., O. Acheampong-Boateng, D. Norris, \& T. J. Ligaraba. 2010. Response of Ross 308 and Hubbard broiler chickens to feed removal for different durations during the day. Trop. Anim. Health. Prod. 42:1421-1426. DOI: 10.1007/ s11250-010-9568-4.

Bokkers, E. A. M. \& P. Koene. 2003. Eating behaviour, and preprandial and postprandial correlations in male broiler and layer chickens. Br. Poult. Sci. 44: 538-544. DOI: 10.1080/000 71660310001616165.

Boostani, A., A. Ashayerizadeh, H. R. Mahmoodian Fard, \& A. Kamalzadeh. 2010. Comparison of the effects of several feed restriction periods to control ascites on performance, carcass characteristics and hematological indices of broiler chickens. Braz. J. Poult. Sci. 12: 171-177.

Bovera, F., G. Moniello, N. Deriu, C. Dimeo, W. Pinna, \& A. Nizza. 2007. Effect of diet on metabolic profile of ostriches (Struthio camelus var. domesticus). Trop. Anim. Health Prod. 39: 265-270.

Bratte, L. 2011. Influence of early skip-a-day feed withdrawal on the haematological indices, serum protein and nutrient digestibility of broilers. Pak. J. Nutr. 10: 831-835.

Butler, E. J. 1983. Plasma Proteins. In: Physiology and Biochemistry of the Domestic Fowl, B.M. Freeman, (eds). Academic Press. London. Pp. 935-939.

Cornejo, S., A. C. Gadelha, J. Pokniak, \& G. Villouta. 2007. Qualitative feed restriction on productive performance and lipid metabolism in broiler chickens. Arg. Bras. Med. Vet. Zootec, 59: 1554-1562.

Darras, V. M., S. Van der Geyten, \& E. R. Kuhn. 2000. Thyroid hormone metabolism in poultry; Biotechnol. Agron. Soc. Environ. 4: 13-20.

Decuypere, E., P. Van As, S. Van der Geyten, \& V. M. Darras. 2005. Thyroid hormone availability and activity in avian 
species: a review. Domest. Anim. Endocrin. 29:63-67.

Demir, E., S. Sarica, A. Sekeroglu, M. A. Ozcan, \& Y. Seker. 2004. Effects of early and late feed restriction or feed withdrawal on growth performance, ascites and blood constituents of broiler chickens. Acta Scandinavica, Saction A-Animal Science 54: 152-158. DOI: 10.1080/09064700410004852.

El-Fiky, A., M. Soltan, F. H. Abdou, S. El-Samra, \& B. El-Neney. 2008. Effect of light regime and feeding frequency on some productive, physiological traits and hormonal profiles in broiler chicks. Egypt. Poult. Sci. 28: 711-743.

Gayathri, K. L., K. B. Shenoy, \& S. N. Hegde. 2004. Blood profile of pigeons (Columba livia) during growth and breeding. Comp. Biochem. Phys. A 138:187-192.

Ghazanfari, S., H. Kermanshabi, M. R. Nassiry, A. Goliann, \& A. Salehi. 2010. Effect of feed restriction and different energy and protein levels of the diet on growth performance and growth hormone in broiler chickens. J. Biol. Sci. 10: 25-30.

Gonzales, E., J. Buyse, M. M. Loddi, T. S. Takita, N. Buys, \& E. Decuypere. 1998. Performance, incidence of metabolic disturbances and endocrine variables of food-restricted male broiler chickens. Br. Poult. Sci. 39: 671-678.

Gowenlock, A. H., J. R. McMurray, \& D. M. McLauchlan. 1988. Varley's Practical Clinical Biochemistry. 6th ed. CAS Publishers and Distributors. New Delhi.

Gyorffy, A., A. Sayed-Ahmed, A. Zsarnovszky, V. L. Frenyo, E. Decuypere, \& T. Bartha. 2009. Effects of energy restriction on thyroid hormone metabolism in chickens. Acta Veterinaria Hungarica 57: 319-330. DOI: 10.1556/ AVet.57.2009.2.12.

Harr, K. E. 2002. Clinical chemistry of companion avian species: a review. Vet. Clin. Path. 31:140-151.

Hornick, J. L., C. Van Eenaeme, O. Gerard, I. Dufrasne, \& L. Istasse. 2000. Mechanisms of reduced and compensatory growth. Domest. Anim. Endocrinol. 19: 121-132.

Izotop, Institute of Isotopes Co Ltd. 2010. Assay Procedure Thyroid Hormones using $\mathrm{T}_{3}\left[{ }^{125} \mathrm{I}\right]$ RIA KIT (Ref: RK-6CT1) and $\mathrm{T}_{4}\left[{ }^{125} \mathrm{I}\right]$ RIA KIT (Ref: RK-11CT1). http://www.izotop. hu [10 July 2010].

Jang, I. S., S. Y. Kang, Y. H. Ko, S. Moon, \& S. H. Sohn. 2009. Effect of qualitative and quantitative feed restriction on growth performance and immune function in broiler chickens. Asian-Aust. J. Anim. Sci. 22: 388-395.

Jurani, M., P. Vyboh, M. Zeman, D. Lamosova, L. Kostal, \& P. Blazicek. 2004. Post-hatching dynamics of plasma biochemistry in free-living European starlings (Sturnus vulgaris). Comp. Biochem. Phys. A 138:89-95.

Khajali, F., A. Zamani-Moghaddam, \& E. Asadi-Khoshoei. 2007. Application of an early skip-a-day feed restriction on physiological parameters, carcass traits and development of ascites in male broilers reared under regular or cold temperatures at high altitude. Animal Sci. J. 78: 159-163.

Khetani, T. L., T. T. Nkukwana, M. Chimonyo, \& V. Muchenje. 2009. Effect of quantitative feed restriction on broiler performance. Trop. Anim. Health Prod. 41:379-384. DOI 10.1007/s11250-008-9200-z.

Leveille, G.A., \& H. E. Sauberlich. 1961. Influence of dietary protein level on serum protein components and cholesterol in the growing chick. J. Nutr. 74: 500-504.

Mohebodini, H., B. Dastar, M. Sham-Sharg, \& S. Zarehdaran. 2009. The comparison of early feed restriction and meal feeding on performance, carcass characteristics and blood constituents of broiler chickens. J. Anim. and Vet. Adv. 8: 2069-2074.
Navidshad, B., M. Shivazad, A. Z. Shahneh, \& G. Rahimi. 2006. Effects of feed restriction and dietary fat saturation on performance and serum thyroid hormones of broiler chickens. Int. J. Poult. Sci. 5: 436-440.

Olkowski, A. A., C. Wojnarowicz, S. Nain, B. Ling, J. M. Alcorn, \& B. Laarveld. 2008. A study on pathogenisis of sudden death syndrome in broiler chickens. Res. Vet. Sci. 85 131-140.

Onbasılar, E. E., S. Yalcın, E. Torlak, \& P. Ozdemir. 2009. Effects of early feed restriction on live performance, carcass characteristics, meat and liver composition, some blood parameters, heterophil-lymphocyte ratio, antibody production and tonic immobility duration. Trop. Anim. Health Prod. 41: 1513-1519. DOI: 10.1007/s11250-009-9341-8.

Reyns, G. E., K. A. Janssens, J. Buyse, E. R. Kuhn, \& V. M. Darras. 2002. Changes in thyroid hormone levels in chicken liver during fasting and refeeding. Comp. Biochem.Phys. B 132:239-245.

Rincon, U. M. \& S. Leeson. 2002. Quantitative and qualitative feed restriction on growth characteristics of male broiler chickens. Poult. Sci. 81: 769-788.

Saffar, A. \& F. Khajali. 2010. Application of meal feeding and skip-a-day feeding with or without probiotics for broiler chickens grown at high-altitude to prevent ascites mortality. American J. Animal \& Vet. Sci. 5: 13-19.

Smith, J. W., A. T. Evans, B. Costall, \& J. W. Smythe. 2002. Thyroid hormones, brain function and cognition: A brief. Neurosci. Biobehav. Rev. 26:45-60.

Steel, R. G. D. \& J. H. Torrie. 1991. Prinsip dan Prosedur Statistik. Suatu Pendekatan Biometrik.Terjemahan. Alih bahasa. B. Sumantri. Gramedia. Jakarta.

Susbilla, J. P., I. Tarvid, C. B. Gow, \& T. L. Frankel. 2003. Quantitative feed restriction or meal-feeding of broiler chicks alter functional development of enzymes for protein digestion. Br. Poult. Sci. 44: 698-709. DOI: 10.1080/0007166 0310001643679 .

Svihus, B. \& H. Hetland. 2001. Ileal starch digestibility in growing broiler chickens fed on a wheat-based diet is improved by mash feeding, dilution with cellulose or whole wheat inclusion. Br. Poult. Sci. 42: 633-637. DOI: 10.1080/0007166012008846 1.

Svihus, B., A. Sacranie, V. Denstadli, \& M. Choct. 2010. Nutrient utilization and functionality of the anterior digestive tract caused by intermittent feeding and inclusion of whole wheat in diets for broiler chickens. Poult. Sci. 89: 2617-2625. DOI: 10.3382/ps.2010-00743.

Todini, L. 2007. Thyroid hormones in small ruminants: effects of endogenous, environmental and nutritional factors. Animal. 1: 997-1008. DOI: 10.1017/S1751731107000262.

Todini, L., A. Malfatti, A. Valbonesi, M. Trabalza-Marinucci, \& A. Debenedetti. 2007. Plasma total T3 and T4 concentrations in goats at different physiological stages, as affected by the energy intake. Small Ruminant Research 68: 285290.

Tolkamp, B. J., V. Sandilands, \& I. Kyriazakis. 2005. Effect of qualitative feed restriction during rearing on the performance of broiler breeders during rearing and lay. Poult. Sci. 84:1286-1293.

Zhan, X. A., M. Wang, H. Ren, R. Q. Zhao, J. X. Li, \& Z. L. Tan. 2007. Effect of early feed restriction on metabolic programing and compensatory growth in broiler chickens. Poult. Sci. 86: 654-660. 